\title{
Using Nearpod as a Tool to Promote Active Learning in Higher Education in a BYOD Learning Environment
}

\author{
Mohssen Hakami ${ }^{1}$ \\ ${ }^{1}$ College of Sciences and Arts, Najran University, Saudi Arabia \\ Correspondence: Mohssen Hakami, Assist. Professor of E-Learning, College of Sciences and Arts, Najran \\ University, Saudi Arabia. E-mail: mahakami@nu.edu.sa
}

Received: October 21, 2019

Accepted: December 7, 2019 Online Published: January 6, 2020

doi:10.5539/jel.v9n1p119

URL: https://doi.org/10.5539/jel.v9n1p119

\begin{abstract}
The present study aims to explore Nearpod as a tool to promote active learning in higher education. In this study, Nearpod is regarded as a tool that can be used to enhance teaching and learning for those lectures provided by male instructors to female students at Sharoura College of Science and Arts, Najran University. Hence, the Nearpod is integrated with video-conference learning system which is used as distance learning system to provide lectures by male lecturers to female students who study at a separate campus. Consequently, students' own devices have been used to fulfil learning activities during classes. The author utilized the mainly quantitative research method and designed an electronic learning questionnaire applied to (74) female students. The findings of the study showed that the affordances of Nearpod and the BYOD model have promoted active learning in the classroom. Students were very satisfied with integrated learning environment, and they commended Nearpod in all courses specially those ones taught by video-conference learning system.
\end{abstract}

Keywords: active learning, Nearpod, BYOD, higher education, affordances

\section{Introduction}

During the last years, smart technologies have become a part of our everyday life (Cristol \& Gimbert, 2013). Correspondingly, with the aim to improve students' learning experiences and outcomes, educators have started developing learning environment benefiting from students' devices/technologies. Thus, students are asked to bring their own devices (BYOD) to be used for teaching and learning purposes. As reported in several studies, students' iPads, laptops, tablets and smartphones have been used in students' daily learning at the classroom and learning settings (Kay \& Schellenberg, 2019). Particularly, there is a high growth rate of the use of BYOD model in Higher Education (HE). It is argued that allowing students to use their own devices i.e. smartphones and iPads, can be a useful learning tool to increase interaction during the lectures' time (Aldiab, Chowdhury, Kootsookos, Alam, \& Allhibi, 2019; McClean \& Crowe, 2017). However, the use of such technology needs an adoption of appropriate pedagogies (Emery, 2012; Santos \& Bocheco, 2017). Furthermore, students need to have more opportunities to collaborate and react as active agents in the learning settings (Daniela, Visvizi, Gutiérrez-Braojos, \& Lytras, 2018).

In order to stimulate students to involve in a learning activity, instructors' pedagogical actions are very important to utilize the affordances of learning tools and learning environment (John \& Sutherland, 2005). Accordingly, instructors need to know how to orchestrate interactive actions between them and their students with the support of the features of these learning tools (Hakami, 2013; Kapur \& Bielaczyc, 2012). This potential interaction may not take place if a learning tool is perceived as a presentational tool only (Armstrong et al., 2005). Hence, the role of a faculty in the class needs to be changed from providing knowledge to encouraging learners to involve in active tasks during the lecture time (McClean \& Crowe, 2017; Siani, 2017).

It is reported that for active learning to be applied in higher education, faculty members need to see technology as a tool to promote their teaching and students' learning (Şahin, Muhammed, Kurban, Caroline Fell, \& Mazur, 2019). Active learning can be defined as any learning approach that allows students to do an active learning task and encourage them to think about the activities they are involving in (Matsushita, 2017). In other words, the student practices working, talking, and receiving during the class, which can be used to discriminate between active and passive learning (Johnson, Johnson, \& Smith, 1998). Doing so, a new paradigm of learning would be needed to engage students in active tasks in the class. It is argued that BYOD can serve as a supportive educational tool 
(Cheng, Guan, \& Chau, 2016). Especially, as indicated in several studies, most students are happy to use their own devices for such activities inside/outside the classroom (McClean \& Crowe, 2017). Moreover, as being reported by students, using BYOD model helps them to interact more with each other in the class (Murillo-Zamorano, López Sánchez, \& Godoy-Caballero, 2019).

As indicated by Nikou and Economides (2018), the results of several studies focusing on the effectiveness of mobile learning suggest that mobile learning has the opportunity to improve students' learning achievements, motivation and attitudes. Safar (2018) identifies the effect of using BYOD model on students' learning in a blended learning classroom at Kuwait University (KU). The study shows that BYOD intervention has a significant positive impact on students' learning achievements based on students' improvement test scores. Moreira et al. (2017) evaluate the use of mobile technologies in higher education institutions of the north region in Portugal between 2009 and 2015. They find that mobile technologies were mostly used as a tool rather than as a teaching and learning approach. They suggest that instructors should apply mobile-learning in such ways that increase collaborative learning between students inside/outside the classroom. In a study at the Fujairah Higher Colleges of Technology Foundations Program in the Fujairah Men's College (FMC) and Fujairah Women's College (FWC) in the United Arab Emirates, Ali (2015) investigates how instructors and students use the iPad's technical affordances to create pedagogical affordances designed to construct and promote English language teaching and learning. The data were collected from 14 instructors and 194 students who participated in a survey, observation of six classes, and an interview of five instructors. The study shows that based on the portability of the iPad and its user-friendly functions, instructors and students use iPad to facilitate collaborative learning activities.

However, BYOD model offers a solution for some aspects which hinder improving learning environment; it also brings some challenges that hinder its effective implementation in the learning environment. It is reported that BYOD could disrupt students' learning because students sometimes use their devices to perform non-content related activities. For example, they can read/send/replay text messages or browse the non-relevant websites (Santos \& Bocheco, 2017). Another obstacle is that some students may not be able to bring a high-quality device to the classroom (Kay \& Schellenberg, 2019). Yet, BYOD's portability, ease of use, small investment cost and the potential impact on improving students' learning is beneficial characteristics which lead educators to apply it in HE. Still, one of the most challenges for instructors to deal with in a large class is how to control and engage students in learning activities during the class.

In short, to increase students' interactions, instructors are recommended that there is a need to develop learning activities that rely on students' personal devices and that students should be encouraged to involve in these activities when needed (Santos \& Bocheco, 2017). To do so, some educators have integrated BYOD with applications that make the students' interaction easy during classes i.e., the Nearpod (Nearpod is a web-based learning application that facilitates and controls interactivities during the learning experience settings. For more information please see https://nearpod.com/l/higher-ed/) (Sanmugam, Selvarajoo, Ramayah, \& Lee, 2019). Mattar (2018) indicates that one of the main advantages of using the Nearpod is to support active learning in the classroom since Nearpod offers different types of ways to engage students in the class. Thus, Nearpod is seen as one of the apps. that would increase interactivities and collaboration in the classroom (Dong, Kavun, Senteney, \& Ott, 2018). Since it allows instructors/lecturers to synchronise, present and control materials such as slides and videos during the class time. Also, Nearpod reports student activities during the class, which allows instructors to analyze learning progress. Moreover, it can enhance students' learning experiences and increase students' satisfaction to their learning because it gives students more opportunities to involve in learning activities and dynamic interaction between them (Jing \& Yue, 2016).

\section{Study Background and Context}

In the Saudi education system, males and females study in separate campuses. This gender segregation is based on Islamic values and Saudi culture. Normally, most lectures are delivered by female lecturers at the female campus. However, due to lack of female lecturers to cover all courses, some lectures have to be taught by male lecturers. To deal with this issue, a video-conference system (closed-circuit television) is being provided to support communication with female students in their campus by creating several units of the system in the male campus. Each unit of the system consists of a PC, a sound system, a document camera (doc-cam) and a video camera with a one-way video and a two-way audio broadcast. Sharoura College of Science and Arts, Najran University is one of those colleges using this system in KSA. At the time of this study, 5 units of the system are being connected to 5 classrooms at the female campus, which are provided with a sound system and a data show in each class. These units are being used to cover all lectures taught by male faculty members and allow them to convey lecture materials into female classrooms. The lecture materials can be a website, show slides, graphics, photos, hand-written notes, video or audio clips, etc. 
To facilitate communication between lecturers and their female students, each lecturer gets assistance from the women's section, which helps him in controlling the class and monitoring the absence of female students. However, as reported in a previous study by the researcher, frequent technical problems and sound unclarity are regarded as the most barriers to instructors' use of the system in their teaching (Hakami, 2017). Although there is only one microphone in the classroom in the women's section which allows female students to ask and answer questions, it is difficult to hear the questions asked by students in the back of the class. Moreover, the echo sound makes it more difficult for both lecturers and students to ask/listen to questions. In fact, teaching via this system is quite challenging especially in large classes because it is difficult to control the class and run active learning tasks. Thus, it is difficult for a lecturer to control students' discussions during the class time. Moreover, the lecturer needs to recognize student's voice or to keep asking, "Please, tell me your name" in order to know the name of the student who asks/answers a question, which wastes class's time.

The main challenge of promoting active learning in a female class, as indicated above, is that all lectures are taught by male instructors to the female students through video-conference learning system with no physical interaction between the lecturers and their female students. It becomes more challenging when lecturing in a large class. Typically, the number of female students in each course taught via the video-conference system does not exceed 30 . However, due to the lack of lectures in the summer semester of 2019, the number of female students enrolled in some courses rose up to 74. Accordingly, Nearpod is considered one of the solutions that could increase the students' interaction. Therefore, it can support learning resources and content across students' smartphones, tablets, and laptops which enable students to actively participate and interact in spite of being applied in large classrooms (McClean \& Crowe, 2017).

Hence, the author combined a "BYOD" model with the Nearpod to create a new learning environment aiming to ease delivering teaching materials and to increase interactivity in the class. In doing so, the author encouraged students to bring their personal smartphones or laptops into the classroom, and used Nearpod to deliver learning materials through these devices. The aim was to utilize the affordances of both tools to create a supportive learning environment. Thus, the Nearpod affordances were used for two reasons: first, to increase the interactivity of the learning environment by involving female students in active learning tasks, asking them to answer different types of questions and easily collecting their responses during the classes. Second, they were used to monitor and control students' activities since Nearpod allows lecturer to present a specific content and control students' devices. However, BYOD model allows students to use their own devices in order to respond to lecturers' instructions. At the same time, since Nearpod does not offer audio conversations service to communicate with learners, the video-conference system was used to broadcast the lecture to all students, communicate with a female student when needed and present written/printed notes to the entire class via the doc-cam attached to the system.

The course name was School Administration and 74 female students were enrolled. The objective of the course was to identify the basic concepts of leadership and develop the abilities and understanding of decision makers to run any educational institutions. Being taught in the summer semester, the course took only 7 weeks from 9 June to 26 July, 2019. The Nearpod was used almost used to provide a third of the lectures especially when there was a need to involve students in discussions and problem-solving tasks.

The free version of Nearpod does have limited number of students to join a class session. Thus, the author's account was upgraded to the Nearpod Platinum Edition to allow 74 students to participate in the learning activities during the class time. By using the Nearpod features, the author converted the designed PowerPoint slides and PDFs into Nearpod classs format and created new ones. In order to promote students' interests and enrich their understanding of the course topics, the author reviewed class Martials and added learning activities, e.g., open-ended questions, quizzes, draw it, and collaborate, multiple choice quizzes, short answers and polls to each one. During each class, the author used his own laptop to run the Nearpod to present and control learning content and activities while simultaneously using the video-conference system to communicate verbally with female students to explain the learning content and give instructions for every learning activity. Benefiting from Nearpod features, the author also kept monitoring students' responses to each learning activity during the classes. Furthermore, by the end of each class, a report on students' participation and performance during each session was saved to be used later for course evaluation.

\section{Study Design}

In the light of the growing body of research evidences that active learning has a positive impact on students' learning outcomes and experiences (Auerbach, Higgins, Brickman, \& Andrews, 2018; Cavanagh et al., 2018; Prince, 2004), in this study, a learning environment was developed in order to increase students' interaction during the class. Accordingly, Nearpod was used to manage learning contents on students' smartphones. At the same time, 
the video-conference system was used for verbal discussions with female students during the class. The contents were a combination of presentations, collaboration activities, and real time assessment activities. Therefore, the main objective of this study is to identify the extent of using the Nearpod in a BYOD learning environment increases/hinders active learning through answering the following research question:

\section{- Do Nearpod affordances promote female students' interaction in a BYOD learning environment?}

To this end, a case study approach was viewed as an appropriate framework to guide this study (Yin, 2003). Hence, quantitative research was considered an appropriate method to explore students' view about the effectiveness of the designed learning environment to promote active learning. Bryman (2012) revealed that, by answering "what" questions and explore opinions, research results can be enriched when using quantitative methods to address the research questions. Accordingly, the researcher designed a questionnaire to obtain students' perspectives towards the effectiveness of learning activities and practices, challenges and limitations when Nearpod being integrated with BYOD model and the video-conference system.

The study questionnaire consisted of four sections, namely, general information, students' opinions about Nearpod usage in the integrated learning environment, a comparison between video-conference usages alone and when integrated with the Nearpod, and general advantages/disadvantages. The second and the third sections used a 5-point Likert Scale, ranging from "strongly disagree" to "strongly agree" to rate female students' views about each item. The fourth section consisted of 5 open-ended questions aiming to provide a rich information about the advantages/disadvantages of using the Nearpod when integrated with video-conference learning system. The questionnaire was reviewed and evaluated by two experts and approved it after considering their comments. The study took place at Sharoura College of Science and Arts, Najran University. All students who enrolled to 'school administration' course took part in the study at the summer semester for the academic year 2018/2019. By the end of the semester, the questionnaire link was sent to all female students enrolled in the course: only 69 out of 74 students participated in the questionnaire with a $92 \%$ response rate.

\section{Data Analysis}

Data was analysed using descriptive statistical analysis. Descriptive statistics consisted of frequency, percentages, means and standard deviation related to questions/items using Excel software. The responses to the open-ended questions were collected in a word document and comments from each participant were grouped under one title: "ST" followed by the questionnaire number e.g., ST01 indicates the comments obtained from the first questionnaire. Then, the researcher inductively started reading the data looking for similarities and differences and making notes of the key ideas. A list of codes was created whereas some codes were revised/deleted.

For reliability analysis, Cronbach's alpha coefficient was computed for the five Likert Scale items in section 2 which elicited students' perspective about Nearpod usage when integrated with video-conference learning system and section 3 which measured students' perspective towards Nearpod, BYOD platform, and video-conference learning system. In both sections, the coefficients were greater than 0.75 indicating a positive reliability. The value of the the Cronbach's alpha was 0.98 for overall 22 items of both sections. For section 2 (13 items), the value of the Cronbach's alpha was 0.9 whereas, for section 3, the value of the Cronbach's alpha of the three positive items was 0.88 and 0.85 for the six negative items.

\section{Results and Discussions}

The qualitative data obtained from open-ended questions indicated that most students were satisfied with the Nearpod usage and its integration with video-conference learning system when using their own devices in the class.

Table shows that the mean score for the total sample of female students' responses regarding Nearpod usage in the class was 3.97, indicating that students perceived the Nearpod as a learning tool which could support their learning in the class when integrated with video-conference learning system. The female students also had a positive attitude towards Nearpod usage when integrated with video-conference learning system. They did not have negative attitudes towards Nearpod usage, BYOD platform and video-conference learning system as explained by the median at 3 and mean at 2.72. Also, most female students "agreed" with the positive items with an average mean 3.89. In other words, students agreed with all positive items and did not agree with negative items which indicate that female students were satisfied with Nearpod usage in the class. ST09 reported that "I hope this application to be used in all courses supported with video-conference learning system". ST20 also added, "I hope other applications, like this one, to be used in order to support learning in the class". 
Table 1. Total central measures for students' responses

\begin{tabular}{lllll}
\hline Item - Satisfaction dimension & N. items & Mean & Median & Mode \\
\hline Students' views about Nearpod usage in the class & 13 & 3.97 & 4 & 4 \\
Students' attitudes towards Nearpod, BYOD platform, and & 3 positive items & 3.89 & 4 & 4 \\
video-conference learning system & 6 negative items & 2.72 & 3 & 2 \\
\hline
\end{tabular}

\subsection{Students' Perceptions of the Nearpod Usage in the Class}

Table 2 below shows the most items that students agreed upon regarding the Nearpod usage when integrated with the video-conference learning system in BYOD platform. As shown in Table 2, 90\% of the students agreed that Nearpod usage increased the interactivity in the class. Moreover, $91 \%$ of the students reported they had the opportunity to work with other students during the classs' time. Likewise, $84 \%$ of the students reported they liked sharing their answers with other students in the class. As explained by ST44, "the most useful thing I liked in using the Nearpod in class is sharing my view and discussing it with other students".

Table 2. Percentage of students' responses towards Nearpod usage during classs

\begin{tabular}{|c|c|c|c|c|}
\hline $\mathbf{N}$ & Items & $\begin{array}{l}\text { Agree } \\
(\%)\end{array}$ & $\begin{array}{l}\text { Natural } \\
(\%)\end{array}$ & $\begin{array}{l}\text { Disagree } \\
(\%)\end{array}$ \\
\hline 1 & Students had more opportunities to work together & 91 & 4 & 5 \\
\hline 2 & The level of interactivity in the class increased & 90 & 3 & 7 \\
\hline 3 & Using the Nearpod's collaborative activities tools increased my understanding & 87 & 3 & 10 \\
\hline 4 & Asking various questions helped me to understand things better & 85 & 10 & 5 \\
\hline 5 & I liked sharing my answer with the class. & 84 & 11 & 5 \\
\hline 6 & The diversity of learning resources increased my understanding of the lectures & 84 & 3 & 13 \\
\hline 7 & $\begin{array}{l}\text { The way of controlling activities and learning materials helped me to be more involved in the } \\
\text { learning process }\end{array}$ & 83 & 8 & 9 \\
\hline 8 & The lectures are explained better & 83 & 6 & 11 \\
\hline
\end{tabular}

Table 2 reveals that the students regarded the integration of the Nearpod as a tool or a learning environment can improve their understanding of the lectures. In other words, the affordance of the Nearpod helped to increase the level of interaction among students and with their instructor, which supported their understanding of the subjects taught. For $87 \%$ of the students indicated that the Nearpod's collaborative activities tools increased their understanding of the classs. Similarly, $84 \%$ of the students reported that the diversity of learning resources had increased their understanding of the lectures. ST34 indicated that "using this App helps to understand lecture better by controlling discussions and questions". This view was reported by $85 \%$ of the students who indicated that asking various questions during the class time helped them to understand things better. This may explain why $83 \%$ of the students reported that the lectures were taught better when the Nearpod was integrated with video-conference learning system. As indicated by Dong et al. (2018), Nearpod can be used to support instructors to involve students in active learning by presenting different learning tasks and learning materials.

\subsection{Students' Perceptions Towards the Integration of Nearpod with Video-Conference System}

Table 3 shows that most female students did not have negative attitudes towards using technologies during the classs' time. However, less than a quarter to almost one third of the students had negative attitudes towards using technologies in general, and Nearpod and the video-conference learning system during the lectures. One reason might be that the integration of Nearpod did not tackle all the issues that hindered learning via using the video-learning system. For example, ST11 reported that "the Nearpod is helpful, but the internet speed and the clarity of sound need to be fixed". ST07 also emphasised that the sound in the class was the most obstacle distracting their learning. Another reason was that although the Nearpod increased the level of interactivities in the class, this level remained lower compared with the physical interaction between students and their instructors. This also might explain why $32 \%$ of female students did not like using new technologies during the lecture. As ST04 said "I don't like learning through the video-conference learning at all". 
Table 3. Percentages of students' perceptions towards the integration of Nearpod with video-conference learning system

\begin{tabular}{|c|c|c|c|c|}
\hline $\mathrm{N}$ & items & $\begin{array}{l}\text { Agree } \\
(\%)\end{array}$ & $\begin{array}{l}\text { Natural } \\
(\%)\end{array}$ & $\begin{array}{l}\text { Disagree } \\
(\%)\end{array}$ \\
\hline 1 & $\begin{array}{l}\text { The video-conference learning system on its own is a better learning tool compared with its } \\
\text { integration with Nearpod }\end{array}$ & 19 & 20 & 61 \\
\hline 2 & Using the Nearpod distracts me from what I should learn & 25 & 27 & 48 \\
\hline 3 & There is no difference in teaching with or without using Nearpod & 23 & 32 & 45 \\
\hline 4 & I learn more when I do not use the Nearpod & 28 & 28 & 44 \\
\hline 5 & I do not like using new technologies during the lecture & 32 & 27 & 41 \\
\hline
\end{tabular}

\subsection{Students' Perceptions Towards Using Their Own Devices}

About third of students reported negative attitudes towards using technologies during the lecture. However, as shown in Table 4, a few students did not love using their own devices in the classroom for learning purposes. Moreover, more than three thirds of the students reported they enjoyed learning when using the Nearpod in the class. As McClean and Crowe (2017) concluded that students liked using their own devices to run learning activities during classs' time. Furthermore, most students did not mind sharing their own devices with her colleagues as reported by $75 \%$ of the students.

Table 4. Percentages of students' perceptions towards BYOD usage

\begin{tabular}{|c|c|c|c|c|}
\hline $\mathrm{N}$ & Items & $\begin{array}{l}\text { Agree } \\
(\%)\end{array}$ & $\begin{array}{l}\text { Natural } \\
(\%)\end{array}$ & $\begin{array}{l}\text { Disagree } \\
(\%)\end{array}$ \\
\hline 1 & I loved using my own device in the classroom for learning purposes & 84 & 9 & 7 \\
\hline 2 & $\begin{array}{l}\text { Personally, I enjoy learning when using the Nearpod integrated with the videoconference } \\
\text { learning system }\end{array}$ & 79 & 9 & 12 \\
\hline 3 & I loved sharing my own device with my colleague sitting nearby in the class & 75 & 16 & 9 \\
\hline
\end{tabular}

It has been turned out that the affordances of BYOD model and the Nearpod have promoted active learning in the classroom. This leads students to decide which apps can be used to support teaching in all courses, especially those ones taught by video-conference learning system. ST13 reported "The video-conference learning system is an old system; the Nearpod and other modern Apps should be used to support teaching and learning in all subjects". This result is consistent with the findings reported by other researchers who confirmed that Nearpod made their classs much easier compared to other app presentations (Gallegos \& Nakashima, 2018; Lowry-Brock, 2016; Siani, 2017).

\section{Conclusion}

The present study aims to identify female students' perspectives about the Nearpod usage when integrated with video-conference learning system in a BYOD learning platform. The study took place at Sharoura College of Science and Arts, Najran University in the summer semester of the academic year 2018/2019. In order to achieve the objectives of this study, a questionnaire was designed and applied to all female students enrolled in the "School Administration" course.

The current results generally show that the features of the Nearpod to present and ask questions (real-time assessment) were reported by students as the most things which encouraged them to involve in learning activities in the classroom. In addition, the way how the Nearpod controls materials helped me as a lecturer and the students to facilitate performing the learning tasks during the lecturing time. The way of Nearpod to control learning activities helped to engage all students in the class and control the learning materials presented to them. As indicated by McClean and Crowe (2017), Nearpod can be used to support instructors to involve students in active learning by presenting different learning tasks and learning materials even in a large class. This result is in consistence with the findings reported by other researchers who reported that Nearpod made their classs much easier compared with other app presentations (Gallegos \& Nakashima, 2018; Lowry-Brock, 2016; Siani, 2017).

As McClean and Crowe (2017) concluded that students liked using their own devices to run learning activities during class, this study shows that students were satisfied with using their own devices for learning proposes. This finding also supports what was reported by Song and Kong (2017) who concluded that BYOD platform was a useful learning environment which could be used to promote teaching activities during the lectures' time. In this study, this type of interactive system was preferred by the students because interaction and sharing knowledge had increased. In addition, students were willing to share and use their devices for the learning purposes. 
In brief, the results of the present study concluded that the affordances of the Nearpod and BYOD platform promote active learning during the lectures and students are willing to involve in this type of learning approach with their own devices being used for such learning activities during classes. These findings have practical implications for lecturers aiming to implement active learning in the learning settings. I argue that by understanding the affordances of such tools/learning environment, it might be better to design a learning setting that leads to improve teaching and learning process. However, the role of lecturer needs to be changed from providing knowledge to facilitating students' learning, taking into account the importance of using the appropriate learning tools suitable for the learning setting. In doing so, more efforts need to be done by HE (Higher Education) to understand which emergent aspects should be taken into account in order to improve teaching and learning environment. Specifically, many researches need to be carried out to determine how the integration of a learning tool with BYOD platform could be used to promote active learning in higher education.

\section{References}

Aldiab, A., Chowdhury, H., Kootsookos, A., Alam, F., \& Allhibi, H. (2019). Utilization of Learning Management Systems (LMSs) in higher education system: A case review for Saudi Arabia. Energy Procedia, 160, 731737. https://doi.org/10.1016/j.egypro.2019.02.186

Ali, B. H. (2015). Pedagogical Affordances, Challenges \&amp; Limitations of the iPad as it is Used in the Foundations Program of the Fujairah Higher Colleges of Technology in the United Arab Emirates (University of Exeter). Retrieved from https://ore.exeter.ac.uk/repository/handle/10871/23928

Armstrong, V., Barnes, S., Sutherland, R., Curran, S., Mills, S., \& Thompson, I. (2005, November 16). Collaborative research methodology for investigating teaching and learning: The use of interactive whiteboard technology. Educational Review, 57, 457-469. https://doi.org/10.1080/00131910500279551

Bryman, A. (2012). Social research methods. Retrieved from https://www.google.com/search?client=firefox-b-d\&q=Social+Research+Methods\%2C+4th+Edition+by+A lan+Bryman

Cheng, G., Guan, Y., \& Chau, J. (2016). An empirical study towards understanding user acceptance of bring your own device (BYOD) in higher education. Australasian Journal of Educational Technology, 32(4), 1-17. https://doi.org/10.14742/ajet.2792

Cristol, D., \& Gimbert, B. (2013). Academic Achievement in BYOD Classrooms. QScience Proceedings, 2013(3), 15. https://doi.org/10.5339/qproc.2013.mlearn.15

Daniela, L., Visvizi, A., Gutiérrez-Braojos, C., \& Lytras, M. D. (2018). Sustainable higher education and $\begin{array}{lllll}\text { Technology-Enhanced } \quad \text { Learning } & \text { (TEL). Sustainability } & \text { (Switzerland), } & \text { 10(11). }\end{array}$ https://doi.org/10.3390/su10113883

Dong, Y., Kavun, N., Senteney, M., \& Ott, J. (2018). Interactive Presentation Tools Using Mobile Devices. Society for Information Technology \& Teacher Education International Conference, 2018(1), 743-748. Retrieved from http://www.learntechlib.org/p/182605/

Emery, S. (2012). Factors for Consideration when Developing a Bring Your Own Device (BYOD) Strategy in Higher Education. 2012, 1277(July 2012), 1-111. https://doi.org/http://hdl.handle.net/1794/12254

Gallegos, C., \& Nakashima, H. (2018). Mobile devices: A distraction, or a useful tool to engage nursing students? Journal of Nursing Education, 57(3), 170-173. https://doi.org/10.3928/01484834-20180221-09

Hakami, M. (2017). Utilization of Virtual Classroom System in Traditional Teaching: Benefits and Challenges. International Journal of Education, Learning and Development, 5(3), 21-29. Retrieved from https://www.eajournals.org/journals/international-journal-of-education-learning-and-development-ijeld/vol5-issue-3-may-2017/utilization-virtual-classroom-system-traditional-teaching-benefits-challenges/

Hakami, M. A. (2013). Teachers' and Students' Use of ICT in the Kingdom of Saudi Arabia (University of Bristol). Retrieved from https://ethos.bl.uk/OrderDetails.do?uin=uk.bl.ethos.602347

Jing, T. W., \& Yue, W. S. (2016). Real-Time Assessment with Nearpod in the BYOD Classroom. In Assessment for Learning Within and Beyond the Classroom (pp. 103-107). https://doi.org/10.1007/978-981-10-0908-2_10

John, P., \& Sutherland, R. (2005, November 16). Affordance, opportunity and the pedagogical implications of ICT. Educational Review, 57, 405-413. https://doi.org/10.1080/00131910500278256

Johnson, D., Johnson, R., \& Smith, K. (1998). Active Learning: Cooperation in the College Classroom. The 
Annual Report of Educational Psychology in Japan, 47. https://doi.org/10.5926/arepj1962.47.0_29

Kapur, M., \& Bielaczyc, K. (2012). Designing for Productive Failure. Journal of the Learning Sciences, 21(1), 45 83. https://doi.org/10.1080/10508406.2011.591717

Kay, R., \& Schellenberg, D. (2019). Comparing BYOD and one-to-one laptop programs in secondary school classrooms: A review of the literature. Society for Information Technology, 2019(April), 6. Retrieved from https://www.learntechlib.org/primary/p/207900/

Lowry-Brock, M. R. (2016). The effect of using Nearpod as a tool of active learning in the high school science classroom. Montana State University, Bozeman, Graduate School. Retrieved from https://scholarworks.montana.edu/xmlui/handle/1/10072?show=full

Maguire, M., Maguire, M., \& Delahunt, B. (2017). Doing a thematic analysis: A practical, step-by-step guide for learning and teaching scholars. AISHE-J - The All Ireland Journal of Teaching and Learning in Higher Education, 9(3). Retrieved from https://ojs.aishe.org/index.php/aishe-j/article/view/335

Matsushita, K. (2017). An invitation to deep active learning. In Deep Active Learning: Toward Greater Depth in University Education (pp. 15-33). https://doi.org/10.1007/978-981-10-5660-4_2

Mattar, J. (2018). Constructivism and connectivism in education technology: Active, situated, authentic, experiential, and anchored learning. RIED. Revista Iberoamericana de Educación a Distancia, 21(2), 201. https://doi.org/10.5944/ried.21.2.20055

McClean, S., \& Crowe, W. (2017). Making room for interactivity: Using the cloud-based audience response system Nearpod to enhance engagement in lectures. FEMS Microbiology Letters, 364(6). https://doi.org/10.1093/femsle/fnx052

Moreira, F., Ferreira, M. J., Santos, C. P., \& Durão, N. (2017). Evolution and use of mobile devices in higher education: A case study in Portuguese Higher Education Institutions between 2009/2010 and 2014/2015. Telematics and Informatics, 34(6), 838-852. https://doi.org/10.1016/j.tele.2016.08.010

Murillo-Zamorano, L. R., López Sánchez, J. Á., \& Godoy-Caballero, A. L. (2019). How the flipped classroom affects knowledge, skills, and engagement in higher education: Effects on students' satisfaction. Computers and Education, 141. https://doi.org/10.1016/j.compedu.2019.103608

Nikou, S. A., \& Economides, A. A. (2018). Mobile-based assessment: A literature review of publications in major referred journals from 2009 to 2018. Computers and Education, 125, 101-119. https://doi.org/10.1016/j.compedu.2018.06.006

Safar, A. H. (2018). BYOD in higher education: A case study of Kuwait university. Journal of Educators Online, 15(2). https://doi.org/10.9743/jeo.2018.15.2.9

Şahin, M., Kurban, C. F., \& Mazur, E. (2019). The new university model: flipped, adaptive, digital and active learning (FADAL). Retrieved from https://openaccess.mef.edu.tr/xmlui/handle/20.500.11779/1139

Sanmugam, M., Selvarajoo, A., Ramayah, B., \& Lee, K. W. (2019). Use of Nearpod As Interactive Learning Method (vol. 1, pp. 8908-8915). INTED2019 Proceedings. https://doi.org/10.21125/inted.2019.2219

Santos, I. M., \& Bocheco, O. (2017). University students' perceptions of personal mobile devices in the classroom and policies. In Smart Technology Applications in Business Environments (pp. 303-320). https://doi.org/10.4018/978-1-5225-2492-2.ch014

Siani, A. (2017). BYOD strategies in higher education: current knowledge, students' perspectives, and challenges. New Directions in the Teaching of Physical Sciences, 12. https://doi.org/10.29311/ndtps.v0i12.824

Song, Y., \& Kong, S. C. (2017). Affordances and constraints of BYOD (bring your own device) for learning in higher education: Teachers' perspectives. In Emerging Practices in Scholarship of Learning and Teaching in a Digital Era (pp. 105-122). https://doi.org/10.1007/978-981-10-3344-5_7

Yin, R. K. (2003). Case study research: Design and methods. Sage publications.

\section{Copyrights}

Copyright for this article is retained by the author, with first publication rights granted to the journal.

This is an open-access article distributed under the terms and conditions of the Creative Commons Attribution license (http://creativecommons.org/licenses/by/4.0/). 